\title{
Internalization of Entrepreneurial Values on Written Batik Craftsmen in Creating Business Independence
}

\author{
Wening Patmi Rahayu ${ }^{1 *}$, Djoko Dwi Kusumojanto², Novia Tri Hapsari ${ }^{3}$, Indrayani ${ }^{4}$, \\ Agus Wibowo ${ }^{5}$ \\ 1, 2, 3, 4, 5 State University of Malang, Malang, Indonesia, \\ *Corresponding auhthor. Email: wening.patmi.fe@um.ac.id
}

\begin{abstract}
This research examines the implementation of the entrepreneurial values internalization, its benefits, and impacts in establishing business independence in the written batik industry. The internalization of entrepreneurial values needs to be instilled in batik craftsmen to maintain their business. It helps individuals develop a creative, resilient, unyielding, honest, and good personality. This was a case study that utilized a qualitative approach design. The research data was extracted using key and supporting informants, specifically business owners and employees and customers. The snowball sampling technique was used to collect the informant data. Furthermore, data analysis involved reduction, display, verification, and drawing conclusion, while triangulation was used to determine the validity of data sources and methods. The results showed that business owners and employees implement entrepreneurial values, including responsibility, knowledge of personal abilities, good personality, creativity, innovation, and courage to take risks. The internalization of entrepreneurial values implanted and implemented fosters creativity and innovation in creating new batik motifs. Creativity and innovation are the main keys to business independence, which is essential for sustainability.
\end{abstract}

Keywords: Internalization, Entrepreneurial Values, Business Independence.

\section{INTRODUCTION}

Small businesses' success is determined by the spirit of entrepreneurship, which is a form of personality embedded through entrepreneurial values. In general, entrepreneurial values consist of characters internalized and considered correct, such as personalities with creative responses, happy to try, face obstacles, confidence, a good locus of control, overcome risks, view change as opportunities, open to various choice, initiative, achievement motivation, professional, respect for time, and insightful [1]-[6].

In the last 13 years, the batik craftsmen in Celaket Malang City have undergone extraordinary developments. This is evidenced by the ownership of several outlets/shops/boutiques selling the typical Malangan batik products. Additionally, various hundreds of batik motifs typical of Malangan have been produced. Craftsmen have produced both written and printed batik. The various motifs include the base of
Badut temple, Malang monument, a white lion's hair, lotus flowers, soybeans, tendrils, leaves, caterpillars, manggar flowers, and coffee beans.

The potential of batik in Malang city needs to be developed. The creativity of the art is often shown at the Malang batik festival. Usually, the public knows, loves, and uses Malangan batik as one of the superior products. The festival also aims to increase the volume of demand and sales. This boosts the income of the batik craftsmen and their businesses.

For 13 years, the batik boutique has shown its independence in maintaining the business with various obstacles. Batik craftsmen and boutique owners have entrepreneurial value as a potential that researchers need to explore. This includes how to internalize entrepreneurship's value in the creative batik industry, how the independent batik creative industry survives, even during Covid 19 pandemic and the new normal. It 
might have been challenging for the craftsmen to survive.

Independence is an individual condition that involves not relying on power or requiring direction from others. According to Parker, independence is not completely dependent on others [7]. Independent people refuse interference from others in their own business [8]. The characteristics of an independent person include having a sense of responsibility, not dependent on others, meeting basic needs (economic and social), a high work ethic, discipline, and dare to take risks [9].

The independence of the batik boutique owner involves the procurement of festivals. The Malang batik exhibition is carried out independently as the organizer. Furthermore, the boutique owner also carries out social activities for helping the less fortunate communities around Celaket, such as providing free groceries. The owner has several craftsmen living around the boutique to provide work opportunities for the community.

Internalization of entrepreneurial values is a process of conveying knowledge, skills to business actors to develop and increase the knowledge and skills necessary to improve their business [10]-[13]. To advance, business actors need knowledge and skills in both the home and creative industries. Seminars, training, and entrepreneurship socialization, are the most appropriate ways of improving business actors' soft skills, including MSME and novice entrepreneurs. The objectives of internalizing business actors' entrepreneurial value include obtaining work standards, having sufficient knowledge, increasing work productivity, improving performance, creating innovations, forming good attitudes, and having sufficient expertise [14].

Internalization of entrepreneurial values is essential in developing an attitude of the initiative, holistic creativity, sensitivity, care, independence, innovation, opportunities for critical thinking, honesty, responsibility, and daring to take risks [15]-[17]. Entrepreneurial value is a prerequisite to entrepreneurial attitudes [16].

Strengthening entrepreneurial values positivelyaffects entrepreneurial behavior [5]. Increasing entrepreneurial value leads to business independence. Islamic entrepreneurial values' internalization includes honesty, hard work, right promises, orderly administration, praying, and paying zakat [18]. It also has an impact on business success.

This research design is based on previous research entrepreneurial values are well internalized and can be conducted among vocational high school, high school students in entrepreneurship learning, and at MSMEs [6], [19], [20].

The internalization of entrepreneurial values is essential in maintaining the batik business in Malang.
During its development, the owners and craftsmen of written batik have an entrepreneurial value, a potential that researchers need to explore. This includes the internalization of entrepreneurial values in the creative batik industry, how independent batik creative businesses survive today, and during the Covid 19 pandemic. In the last five months now, the number of shops/outlets/boutiques has decreased due to the pandemic. However, some have survived in the new normal conditions. The internalization of entrepreneurial values is an important aspect to study, especially for existing batik craftsmen. Moreover, competition is also a threat to batik craftsmen and business owners.

This research can be used to instill entrepreneurial values to craftsmen as part of the creative industry, and in forming and increasing their creativity. It also shows that entrepreneurial values' internalization establishes independence and business sustainability under normal and new normal conditions.

This research's novelty is independence and business sustainability to rise when normal, and new normal conditions in the batik business are part of the creative industry.

\section{METHODS}

This was a case study designed using a qualitative approach. It aims to determine the subjects' experiences, including attitude, understanding, motivation, and activity. This is achieved holistically through descriptions in words and language in a realistic situation using a natural method [21].

The research was carried out on batik owners and craftsmen at the Batik Tulis Celaket Boutique in Malang City. This location was selected because the boutiques and craftsmen survive both in normal, the Covid 19 pandemic, and the new normal.

The study used key and supporting informants, specifically batik boutique owners and employees and customers. The samples were selected based on snowball sampling with certain criteria. Initially, only one or two people were selected. However, since the data was not complete, the researchers looked for other people capable of completing it from the previous informants.

Data collection techniques used include an interview, observation, and documentation study [22]. Table 1 shows the points of the interview instrument.

Data analysis techniques used involved data reduction, display, verification, and drawing conclusions. The reduction process is carried out by summarizing, determining important and deleting unimportant data, and carrying out coding. Data display involves processing the data into narrative text and short 
descriptions. Researchers try to organize data in an organized and patterned manner based on the field findings. Afterward, the data is verified, and the conclusions are made.

Table 1. The Points of Interview Instruments regarding Internalization of Entrepreneurial Values at Batik Boutique

\begin{tabular}{|c|c|c|c|}
\hline \multirow{2}{*}{\begin{tabular}{|c|} 
Variables \\
\end{tabular}} & \multirow[b]{2}{*}{ Research Indicators } & \multirow[b]{2}{*}{ Items } & \multirow[b]{2}{*}{ Description } \\
\hline & & & \\
\hline \multirow{18}{*}{$\begin{array}{l}\text { Internalization of } \\
\text { Entrepreneurial } \\
\text { Values }\end{array}$} & \multirow{5}{*}{$\begin{array}{l}\text { Knowledge of the business } \\
\text { being carried out, the } \\
\text { environment }\end{array}$} & how long the business established & \multirow[t]{5}{*}{ Key Informant } \\
\hline & & $\begin{array}{l}\text { The reason for establishing a written } \\
\text { batik business }\end{array}$ & \\
\hline & & Obstacles encountered & \\
\hline & & Targeted market share & \\
\hline & & $\begin{array}{l}\text { The difference from other written batik } \\
\text { businesses }\end{array}$ & \\
\hline & \multirow{5}{*}{$\begin{array}{l}\text { Knowledge of roles, } \\
\text { responsibilities }\end{array}$} & Entrepreneurial role & \multirow{5}{*}{$\begin{array}{l}\text { Key Informants, } \\
\text { Supporting } \\
\text { Informants } \\
\text { (Employees) }\end{array}$} \\
\hline & & Entrepreneurial responsibility & \\
\hline & & Responsibility to pay taxes & \\
\hline & & Create jobs & \\
\hline & & Batik waste disposal & \\
\hline & \multirow[t]{3}{*}{$\begin{array}{l}\text { Knowledge of personality, } \\
\text { abilities }\end{array}$} & Ability to manage business & $\begin{array}{l}\text { Key Informants, } \\
\text { Supporting } \\
\text { Informants } \\
\text { (Karvawan) }\end{array}$ \\
\hline & & Employee capabilities & $\begin{array}{l}\text { Key Informants, } \\
\text { Supporting } \\
\text { Informants } \\
\text { (Employees and } \\
\text { Customers) }\end{array}$ \\
\hline & & $\begin{array}{l}\text { Give an example of a good personality } \\
\text { (honest, responsibility, friendly, } \\
\text { discipline) }\end{array}$ & $\begin{array}{l}\text { Key Informants, } \\
\text { Supporting } \\
\text { Informants } \\
\text { (Employees and } \\
\text { Customers) }\end{array}$ \\
\hline & \multirow[t]{5}{*}{ Creativity and Innovation } & Batik motif creativity & \multirow{5}{*}{$\begin{array}{l}\text { Key Informant } \\
\text { Supporting } \\
\text { Informants } \\
\text { (Employees and } \\
\text { Customers) }\end{array}$} \\
\hline & & Color combinations & \\
\hline & & Batik types & \\
\hline & & Combination of ingredients & \\
\hline & & The shape of batik products & \\
\hline & \multirow{5}{*}{$\begin{array}{l}\text { Taking risks in both the } \\
\text { unexpected conditions of } \\
\text { Covid } 19 \text { and the new } \\
\text { normal }\end{array}$} & Dare to take risks & \multirow{5}{*}{$\begin{array}{l}\text { Key Informant } \\
\text { Supporting } \\
\text { Informants } \\
\text { (Employees) }\end{array}$} \\
\hline & & Risks with competitors & \\
\hline & & Unexpected risks & \\
\hline & & $\begin{array}{l}\text { The employees are in unexpected } \\
\text { conditions. }\end{array}$ & \\
\hline & & the sustainability of the batik business & \\
\hline \multirow{7}{*}{$\begin{array}{l}\text { Business independence } \\
\text { both under normal } \\
\text { conditions, Covid } 19 \\
\text { pandemic, new normal }\end{array}$} & $\begin{array}{l}\text { Responsible to the batik } \\
\text { boutique business }\end{array}$ & Responsible for the batik business & \multirow[t]{7}{*}{ Key Informant } \\
\hline & \multirow{2}{*}{$\begin{array}{l}\text { Meet the needs of the own } \\
\text { business }\end{array}$} & Economic aspects of business needs & \\
\hline & & The social aspect of business needs & \\
\hline & \multirow[t]{2}{*}{ Never give up } & Tenacious/painstaking & \\
\hline & & Strong determination & \\
\hline & Able to make decisions & Able to make decisions & \\
\hline & Able to compete & Able to compete & \\
\hline
\end{tabular}




\begin{tabular}{|l|l|l|l|}
\hline & Dare to take risks & Able to compete & \\
\hline
\end{tabular}

(Sources: [5], [18], [23]-[25], processed by researchers, 2020)

governments in introducing batik products. Advantageously, many batik craftsmen have appeared in cities and regencies that carry Malangan batik motifs.

Malang, as a tourism city, is supportive of local wisdom products. From tourism, Malang batik business is an icon for local wisdom products. Many tourists visit the Celaket batik boutique and eventually buy the products because the unique motifs and colors attract them. Many customers come from abroad. They learn about batik boutiques from friends, exhibitions, Facebook, and Instagram. Business owners use promotional media because it makes batik products known and remembered and may influence consumers purchasing decisions. Promotions carried out by boutique owners are in line with Kotler's which stated that promotion aims to communicate products/services to target markets [28]. It conveys information about their advantages, uses, and existence to change attitudes and influence, promoting people to buy products/services. This is also in line with previous research, which proved that promotional media affects potential consumer purchase intentions and decisions [29]-[31]. Sales media increase sales turnover and strengthen small businesses' position [32].

Celaket's batik boutique business has unique motifs and always changes their design, hence buyers do not feel bored. The business has a competitive edge since there are many motifs, not monotonous, and the batik color is unique. The typical Malangan batik has motifs, including the Malangan mask, clown temple base, Malang monument, white lion hair, lotus flower, spattered soybeans, tendrils, caterpillars, manggar flower, and coffee bean. The various kinds of batik motifs produced proofs the business owner's creativity.

\subsection{Internalization of Entrepreneurial Values in Batik makers at Celaket written Batik Boutiques}

The potential of written batik in Malang as a local wisdom product needs to be developed, including the business owners' role in internalizing their employees' entrepreneurial values. Various internalization forms of entrepreneurial values instilled by business owners include the following.

Responsible. Batik boutique business owners run businesses responsibly. Business continuity responsibility includes quality control of the batik process and products, providing training to new employees for a month, and paying attention to consumer satisfaction in batik quality and service. 
The owner also should pay taxes, which contributes to regional income. Concerning business ethics, owners also pay attention to batik waste. In general, batik waste is not immediately disposed of. A reservoir is made to functions as the first waste disposal and decomposition before it is disposed of. Business owners pay attention to environmental issues, including water and soil pollution.

Business owners take various forms of responsibility, hence gain a positive image before employees. The responsibilities of boutique owners have a positive impact on their employees. For instance, employees imitate work based on their responsibilities in making batik, dyeing, drying the coloring results, printing batik motifs, packaging, maintaining boutiques, and serving buyers.

Self-Abilities Knowledge. The owners understand their batik business. They are very creative in making batik concepts from start to finish. Everything related to the typical Malangan batik motif design is conducted individually. The concept update is carried out regularly, hence the business is not monotonous. Quality control is a major concern in running their batik business.

Managing the business requires promotion through exhibitions and entertainment. The exhibition events are carried out by inviting several artists to wear new products produced. This activity promotes written batik products. Their family members also supported the promotion by wearing the batik produced. Therefore, many people are interested in buying after seeing the batik results at the batik boutique.

The skills of making, dyeing, and drying batik are taught to employees. For this reason, they gain the ability to make written batik. New employees are always trained and introduced to batik motifs to develop the competence required. Employees work with a tenacious and diligent attitude.

The ability to compete in running a business is extraordinary. The owners compete in their business and may last for 13 years. The key to success lies in the batik quality, which is always maintained to ensure customers are satisfied and ultimately make repeat purchases.

Personality Values. Batik boutique business owners always show good personality values to their employees, including honesty, responsibility, friendly, and discipline at work. The personality is followed by employees. Respect is an impetus to follow the good personality of the business owner.

Good role models from business owners and their families are important in instilling personality values. Family members are often hardworking and serve everyone with impartiality.
Employees' personality values at work include serving customers deftly, friendly, patiently, thoroughly, and courteously. Employees patiently explain batik motifs and how to care for written batik for customers feel helpful and at ease when buying. Buyers are satisfied shopping at the Celaket batik boutique because they choose freely.

Business owners and employees provide honest service in demonstrating the fine, medium, and less essential batik quality. Customers feel comfortable shopping for batik in boutiques because of receiving real information. The neat arrangement of batik is a concern for employees.

Creativity and Innovation. Boutique owners show creativity in batik design. Various batik motifs are made by presenting the Malang icon. Giving details of a striking batik color is an innovation.

The innovation of giving written bright and striking colors is displayed in the products. The color is striking but still elegant with a combination of patterns, giving a cheerful aura. The color combination, both striking and muted, attract buyers. Batik motifs and colors are the creativity presented, making the product attractive to the market. In making this batik design, a touch of instinct and the artistic soul is required.

Other innovations are evident in the batik produced, including hand-written, printed, and written batik materials. Apart from the lower price, the quality of the fabric is better. The innovation of batik products can also be seen in the diversity of fabrics, various clothes, bags, hats, shoes, and accessories. Variations of the product sold meet customer demands.

Courage to Take Risks. The business activities carried out to prove that owners may compete favorably. Various obstacles, such as the risk of unsold goods and slow capital turnover, does not dampen business enthusiasm. Employees continue to work even though the boutique is not selling well. Although the owner experiences ups and downs, extraordinary enthusiasm is the motivation to help employees. There are always solutions, including business capital loans for MSMEs, free product innovation training, ease of participating in exhibitions, obtaining batik orders from various agencies.

Enthusiasm, tenacity, diligence, and painstaking is the business philosophy. The business owner has noble intentions and a strong determination to help the Celaket community, which is welcomed by the employees. The batik boutique employees are very loyal to this business because they feel that it is a part of their life and source of family livelihoods. The owners consider them as capital in strengthening their business.

Business activities always have risks, which can be minimized with innovation, creativity, promotion 
through social media, and directly to customers. Not only business owners who carry out promotions but also employees are involved in promoting. This is carried out to minimize risk and increase sales.

The things carried out by boutique owners to internalize entrepreneurial values to their employees are in line with previous research. These studies established the entrepreneurial values that should exist in an entrepreneur, including independence, creativity, ability to manage risks, focus on action, leadership spirit, realistic, curious, committed, communicative, responsible, tenacious, and hard working [2], [4].

Entrepreneurial values include self-confidence, focus on goals, ability to manage risks, responsibility, honesty, working hard, have leadership, focusing on the future, and original ideas [10]. Four entrepreneurial values: independence, creativity, ambition, and courage [33].

\subsection{Benefits of Internalizing Entrepreneurial Values in Batik in Employees}

The internalization of entrepreneurial values has the following benefits.

1) Increased creativity creates the innovative character of employees in pursuing typical Malangan written batik. Employees' training includes introducing and improving their batik skills, making them skilled, creative, and more focused. Creativity and innovation are essential in shaping independence and business sustainability.

2) Forms professionalism by improving good personality values, such as honesty, diligence, resilience, never giving up, responsibility, and caring for others. Business owners exemplify personality values as a form of entrepreneurial values internalization instilled in employees. As a result, a good personality characterizes employees' lives at work. Professionalism supports more effective and efficient work and creates new innovations.

3) Improve work quality based on standards. The business owner can control the results of the batik process. Quality control is the standard for the performance of craftsmen.

4) Build cooperation. The entrepreneurial values internalization shapes the business owners' behavior in building good relationships with partners, employees, and customers.

5) Owners and employees have sensitivity and concern for the community welfare in the environment around the business.

6) Increase the independence of employees in entrepreneurship. It can find and create business opportunities.
7) Increase the employees' risk-taking attitude in entrepreneurship.

The benefits felt by owners and employees include being achieving work standards, increasing useful knowledge in running a business, work productivity, problem-solving skills, and forming entrepreneurial attitudes and skills [14]. This is in line with previous research, which stated that through entrepreneurial internalization, a person could create small businesses by making culinary products, crafts, and offline and online trading platforms [19], [34]. Similarly with this statement established that internalization through entrepreneurship training activities forms and increases motivation, the ability to identify business opportunities and resources and improve and develop entrepreneurial skills [35], [36]. The objectives of the internalization of the entrepreneurial values include creating a generation with sensitivity and concern for the welfare of society; an open and independent generation, can find and create opportunities by thinking critically, having creative, and innovative ideas, and creating a generation that can propose innovative ideas based on honesty, responsibility and caring for others [17].

Creating a generation not afraid to take risks and applying innovative ideas in real life is beneficial to employees in written batik boutiques. Employees become skilled and have the capital to make their own batik business.

\subsection{Business Independence in Internalizing Entrepreneurial Values}

In running a business, an unyielding, persistent, and resilient nature and attitude have always been intrinsic motivations because the business has lasted for 13 years.

A business owner's courage to make decisions related to his business is based on various considerations to minimize risk. It is necessary to make decisions related to business development, competitive strategies, product innovation, prices, and promotions. Someone with the ability to make decisions could be used as learning tools to become entrepreneurs and develop entrepreneurial attitudes [37]. An entrepreneur needs to be able to develop his profession, namely the ability to make decisions.

The competitive ability owned and implemented in the batik boutique business's independence is evident in the quality control of the batik produced. In case the batik does not pass the quality control, it cannot be sold. Batik quality is a top priority for batik boutique owners that need to be maintained.

The key to independence in carrying out business activities depends on how the batik boutique owner introduces, exemplifies, and implements entrepreneurial 
values and good personality to employees. The role models are the batik boutique owner and their families, hence their behavior becomes inspirations and an example to employees. Being honest, responsible, disciplined, unyielding, tenacious, diligent, painstaking, thorough, nimble, patient, friendly, polite, and neat are part of business independence. Someone with independence show an explorative attitude, dare to make decisions, be creative, confident, skilled, respect time, and be responsible [38], [39]. Steinberg classified independence into three forms, including emotions, behavior, and values [40]. The description of a person's entrepreneurial independence is responsible, not dependent on others, can fulfill basic needs, is diligent, and dares to take risks [41]. Entrepreneurial independence includes aspects of self-confidence, working without depending on others, respecting time, being action-oriented, willingness to progress, achieving, innovating, being able to control self, honesty, responsibility, and ability to make decisions [42]-[44].

Employees' personality value and knowledge about written and stamped batik produced is shown to customers. This makes them comfortable and happy shopping at the batik boutique. Since the commodities demanded are available in the batik boutique, customers feel satisfied. Additionally, they can make repeated purchases due to the good personality values of the owners.

Another key to business independence is innovation in batik motifs. The innovation is conducted to make consumers impressed with the typical Malangan batik, an icon of Malang. In innovating batik motifs, creativity is needed to suit customer tastes. The typical Malangan motifs designed in every batik product are combined beautifully. This is where the market's creativity in designing the motifs is tested. In general, creativity never runs out and is the key to success. It is also shown by using bright and striking colors with a blend of beauty, grace, and charm. Malangan batik motif innovation and color combination make businesses survive and exist. Innovation is a way of building, developing business through new technology, new applications in the form of products and services, expanding market segments, and introducing new organizational forms [45]. For this reason, various forms of innovation form an innovation arena. Innovative products/services can be carried out by developing new product attributes, improving quality, and developing product models and sizes [28]. Additionally, Innovation is the main key in improving the quality of production processes, hence products and services maintain their existence and compete in the market [46].

This is in line with previous research, which stated that the application of business innovation generates added value, develops products/services and production, and marketing processes to improve performance [47]. Furthermore, innovation and product/service creativity affect the business's success and sustainability [48][50].

Apart from the internalization of entrepreneurial values, creativity, and innovation from the uniqueness of batik, the independence of business formed for 13 years is also influenced by the owner's life philosophy. The philosophies adopted include (1) fortune from Allah is never confused, (2) keep trying, work honestly, painstakingly, diligently, and responsibly, hopefully, there will be results (3) every difficulty must have convenience in it, and (4) employees are business partners. These philosophies make owners survive in running batik businesses. Batik boutique owners have a good locus of control, which helps control events in running their business externally and internally. External locus of control is a condition out of control that affects performance [51]. Contrastingly, internal locus of control is the ability to control events in running a business and its consequences.

Covid 19 had an extraordinary impact on the batik boutique business. For instance, sales decreased because of the orders significantly. The batik boutique had been closed, and employees were temporarily laid off due to the city government's appeal to suspend the boutique business. At the, there is no batik production or sales.

After the new normal condition, the Celaket batik boutique began to open again, specifically around the beginning of June. Marketing is mostly online because there are few customers in the boutiques, and therefore the production of written and stamped batik is reduced. However, there is still production, though decreasing. Employees in shifts with profits decreasing due to decreased sales. This condition is experienced by all business people worldwide because of Covid 19 pandemic.

The Celaket batik boutique business's independence and sustainability in the new normal era lie in the creativity, uniqueness, and innovation of written and stamped batik. Business owners continue to improve the quality of batik motifs and colors to compete even though production decreases. Employees continue to work in new normal conditions by coming in shifts due to the decline in sales.

The life philosophy in running a business implemented by the batik boutique owner is always upheld. Furthermore, boutique owners often hold good personality values and instill them in their employees, which is essential for business survival. Until the new normal situation, business owners keep their employees working alternately and pay them despite the difficult conditions. Therefore, employees continue to work and earn income, though relatively smaller. 


\section{CONCLUSION}

Based on the discussion of the results, this study makes the following conclusions

1. The implementation of the entrepreneurial value internalization instilled by business owners is a role model for employees.

2. Internalizing entrepreneurial values has several benefits, including increasing employee creativity and innovation, good personality values, work quality, knowledge and skills, a good relationship between business partners, owners, and employees, completion of work more effectively and efficiently, employees independence at work, ability to find and create business opportunities, and dare to take risks in entrepreneurship.

3. Creativity, innovation, working diligently, tenaciously, honestly, and the business owner's philosophy are the keys to shaping business independence and continuity in normal and new normal conditions.

\section{REFERENCES}

[1] J. Anchorena and L. Ronconi, "Entrepreneurship, Entrepreneurial Values, and Public Policy in Argentina," in Entrepreneurship in Latin America: A Step Up the Social Ladder?, 2013.

[2] F. T. Indratno, Membentuk Jiwa Kewirausahaan. Jakarta: Kompas, 2012.

[3] S. R. Mas, "Transformasi Nilai-Nilai Kewirausahaan Pada Siswa SMK," J. Manaj. dan Supervisi Pendidik., vol. 1, no. 1, pp. 115-121, 2017, doi: 10.17977/um025v1i22017p115.

[4] E. Mulyani, "Model Pendidikan Kewirausahaan di Pendidikan Dasar dan Menengah," J. Ekon. dan Pendidik., vol. 8, no. 1, 2012, doi: 10.21831/jep.v8i1.705.

[5] S. Sukirman, "Jiwa Kewirausahaan dan Nilai Kewirausahaan Meningkatkan Kemandirian Usaha melalui Perilaku Kewirausahaan," J. Ekon. dan Bisnis, vol. 20, no. 1, p. 117, 2017, doi: 10.24914/jeb.v20i1.318.

[6] A. Winarno, "Pengembangan Model Pembelajaran Internalisasi Nilai-Nilai Kewirausahaan pada Sekolah Menengah Kejuruan di Kota Malang," J. Ekon. Bisnis, vol. 8, 2009.

[7] R. N. Putra, I. A. Silviandari, and Y. Supriyono, "Hubungan Kemandirian Dengan Intensi Berwirausaha Pada Mahasiswa Universitas Brawijaya Malang," 2014.

[8] M. Ali, Psikologi Remaja (Perkembangan Peserta Didik). Jakarta: Rineka Cipta, 2005.
[9] D. Y. Lutfiansyah, "Pendidikan Kecakapan Hidup (Life Skills) Dalam Pemberdayaan Perempuan Kepala Keluarga (Pekka) Untuk Peningkatan Pendapatan Dan Kemandirian Berwirausaha," J. Pendidik. Luar Sekol., vol. 4, no. 2, 2009.

[10] E. Autio, "Strategic Entrepreneurial Internationalization: A Normative Framework," Strateg. Entrep. J., vol. 11, no. 3, pp. 211-227, 2017, doi: 10.1002/sej.1261.

[11] M. Dahlan, "Peran Pengabdian pada Masyarakat dalam Pemberdayaan Usaha Mikro, Kecil, dan Menengah (UMKM)," J. Pengabdi. Kpd. Masy., vol. 1, no. 2, pp. 81-86, 2017.

[12] S. Sofyan and A. Arief, "Strategi Dinas Koperasi, UMKM, \& Tenaga Kerja Kota Palu Dalam Memberdayakan Usaha Mikro di Pasar INPRES Manonda Palu," Bilancia J. Stud. Ilmu Syariah dan Huk., vol. 11, no. 2, pp. 325-358, 2017, doi: 10.24239/blc.v11i2.309.

[13] A. Verbeke, M. Amin Zargarzadeh, and O. Osiyevskyy, "Internalization theory, entrepreneurship and international new ventures," Multinatl. Bus. Rev., vol. 22, no. 3, pp. 246-269, 2014, doi: 10.1108/MBR-06-2014-0023.

[14] H. Sofyandi, Manajemen Sumber Daya Manusia. Yogyakarta: Graha Ilmu, 2008.

[15] A. Dutta and S. Banerjee, "Does microfinance impede sustainable entrepreneurial initiatives among women borrowers? Evidence from rural Bangladesh," J. Rural Stud., vol. 60, pp. 70-81, 2018, doi: 10.1016/j.jrurstud.2018.03.007.

[16] D. Hendarwan, "Menumbuhkan Jiwa, Perilaku dan Nilai Kewirausahaan Dalam Meningkatkan Kemandirian Bisnis," MBIA, vol. 17, no. 2, p. 10, 2019, doi: 10.33557/mbia.v17i2.340.

[17] Suhariyadi, A. Nugroho, Purwanto, and M. Faturohman, Kewirausahaan: Membangun Usaha Sukes Sejak Usia Muda. Jakarta: Salemba Empat, 2007.

[18] H. Rimiyati and M. Munawaroh, "Pengaruh Penerapan Nilai-Nilai Kewirausahaan Islami Terhadap Keberhasilan Usaha (Studi Pada Pengusaha UMKM Muslim Di Kota Yogyakarta)," J. Manaj. Bisnis, vol. 7, no. 2, p. 28, 2016.

[19] S. Munir and K. D. Yuangga, "Analisis Internalisasi Nilai-Nilai Entrepreneurship Pada Mahasiswa Jurusan Ekonomi Pembangunan Dalam Mata Kuliah Kewirausahaan,” vol. 01, no. 01, pp. 28-33, 2020. 
[20] R. Sahabuddin, "Pengembangan Nilai-nilai Kewirausahaan dalam Meningkatkan Kinerja Usaha Rumput Laut Skala Kecil," Trikonomika, vol. 11, no. 1, p. 15, 2012 .

[21] L. J. Molengo, Metodologi Penelitian Kualitatif. Bandung: Remaja Rosdakarya, 2013.

[22] Sugiyono, Metode Penelitian Kombinasi (Mix Methods). Yogyakarta: Graha Ilmu, 2015.

[23] J. Gwee, Positive Business Ideas: Proven, Practical, and Easy to Apply Ideas to Improve Your Performance. Jakarta: Gramedia Pustaka Utama, 2007.

[24] R. D. Hisrichc, M. P. Peters, and S. A. Dean, Entrepreneurship, 6th ed. Boston: McGraw Hill, 2005.

[25] J. Levie and E. Autio, "A theoretical grounding and test of the GEM model," Small Bus. Econ., vol. 31, no. 3, pp. 235-263, 2008, doi: 10.1007/s11187008-9136-8.

[26] T. W. Zimmerer and N. M. Scarborough, Entrepreneurshipand New Venture Formation. London: Prentice- Hall International, 2012.

[27] Suparyanto, Kewirausahaan Konsep dan Realita pada Usaha Kecil. Bandung: Alfabeta, 2012.

[28] P. Kotler, Manajemen Pemasaran. Jakarta: PT Prenhallindo, 2013.

[29] M.-B. Alexandrescu and M. Milandru, "Promotion as a form of Communication of the Marketing Strategy," L. Forces Acad. Rev., vol. 23, no. 4, pp. 268-274, 2019, doi: 10.2478/raft-2018-0033.

[30] A. Y. P. Chang, "A study on the effects of Sales Promotion on consumer involvement and purchase intention in Tourism industry," Eurasia J. Math. Sci. Technol. Educ., vol. 13, no. 12, 2017, doi: 10.12973/ejmste/77903.

[31] C. J. Gerung, J. Sepang, and S. Loindong, "Pengaruh Kualitas Produk, Harga Dan Promosi Terhadap Keputusan Pembelian Mobil Nissan XTrail Pada Pt. Wahana Wirawan Manado," J. EMBA J. Ris. Ekon. Manajemen, Bisnis dan Akunt., vol. 5, no. 2, pp. 2221-2229, 2017, doi: 10.35794/emba.v5i2.16521.

[32] S. Khairani and R. Pratiwi, "Peningkatan Omset Penjualan Melalui Diversifikasi Produk dan Strategi Promosi Pada UMKM Kerajinan Souvenir Khas Palembang," CARADDE J. Pengabdi. Kpd. Masy., vol. 1, no. 1, pp. 36-43, 2018, doi: 10.31960/caradde.v1i1.18.

[33] W. W. Kirkley, "Entrepreneurial behaviour: the role of values,” Int. J. Entrep. Behav. Res., vol. 22, no. 3, pp. 290-328, 2016, doi: 10.1108/IJEBR-022015-0042.

[34] M. Asri, "Internalisasi Nilai-Nilai Kewirausahaan Pada Mahasiswa Pendidikan Luar Sekolah Fip Unm," vol. 12, no. 52, pp. 147-158, 2020.

[35] S. A. Olugbola, "Exploring entrepreneurial readiness of youth and startup success components: Entrepreneurship training as a moderator," J. Innov. Knowl., vol. 2, no. 3, pp. 155-171, 2017, doi: 10.1016/j.jik.2016.12.004.

[36] Ergen Sitorus, "Evaluasi Program Pelatihan Kewirausahaan Oleh Disnaker Kota Pekanbaru," J. JOM FISIP, vol. 2, no. 2, p. 13, 2015.

[37] Suryana, Memahami Karakteristik Kewirausahaan. Direktorat Pendidikan Menengah Kejuruan. Direktorat Jenderal Pendidikan Dasar dan Menengah Departemen Pendidikan Nasional, 2003.

[38] A. Gea, A. P. Y. Wulandari, and Y. Babari, Character Building 1 Relasi dengan Diri Sendiri. Jakarta: PT Gramedia, 2003.

[39] F. J. Monks, Knoers, and S. R. Haditono, Psikologi perkembangan: Pengantar Dalam Berbagai Bagian. Yogyakarta: Gadjah Mada University Press, 2013.

[40] R. Ginintasi, Kontribusi Pola Pengasuhan Orang Tua Terhadap Perkembangan Kemandirian dan Kreativitas Anak. Bandung: FIP-Universitas Pendidikan Indonesia, 2009.

[41] N. N. A. Firdani, A. Suryadi, and I. Saripah, "Kemandirian Berwirausaha Pemuda Produktif Melalui Program Pendidikan Kecakapan Hidup,” J. Pendidik. luar Sekol., vol. 1, no. 14, 2017.

[42] D. Lee-Ross, "Personality characteristics of the self-employed: A comparison using the World Values Survey data set," J. Manag. Dev., vol. 34, no. 9, pp. 1094-1112, 2015, doi: 10.1108/JMD-062014-0062.

[43] L. Nuryanti, J. Widodo, and U. N. Semarang, "Development of Entrepreneurial Independence Attitudes for Santri ( Case Study at Adh Dhuhaa Islamic Boarding School in Baki District , Sukoharjo Regency )," vol. 7, no. 1, pp. 70-76, 2018 .

[44] A. Syafrina, "Analisis Kemandirian Siswa Dalam Proses Pembelajaran Di Kelas III Sd Negeri 1 Banda Aceh," Pesona Dasar (Jurnal Pendidik. Dasar dan Humaniora), vol. 1, no. 12, 2017.

[45] B. Prakoso, "Pengaruh Orientasi Pasar, Inovasi Dan Orientasi Pembelajaran Terhadap Kinerja Perusahaan Untuk Mencapai Keunggulan 
Bersaing," J. Stud. Manaj. dan Organ., vol. 23, 2005.

[46] A. Hanif and I. A. Manarvi, "Influence of Quality, Innovation and New Product / Services Design on Small and Medium Enterprises," World Congr. Eng. 2009 (Volume 1), vol. I, no. 5, pp. 748-751, 2009.

[47] M. S. Abdurrahman, "Penerapan Inovasi Kewirausahaan Bagi Bisnis Komunikasi Pemula: Studi Kasus Strategi Bisnis di PT Edu Media Komunika," J. Penelit. Komun. dan Pembang., vol. 16, no. 1, p. 11, Feb. 2018, doi: 10.31346/jpkp.v16i1.1334.

[48] T. X. Hua, A. Kabia, and D. Arkady, "Creativity \& Innovation a Road Map to Business Success and Growth in Sierra Leone: From Intuition to Process Management," Glob. J. Manag. Bus. Res., no. 71, 2015.

[49] I. R. Permatasari and A. Sulasari, "KAJIAN PERANAN ORIENTASI WIRAUSAHA DAN INOVASI PRODUK TERHADAP KEBERHASILAN USAHA UMKM DI KOTA MALANG," J. Adminitrasi dan Bisnis, vol. 8, 2019.

[50] K. J. Wu, C. J. Liao, M. L. Tseng, and P. J. Chou, "Understanding innovation for sustainable business management capabilities and competencies under uncertainty," Sustain., vol. 7, no. 10, pp. 1372613760, 2015, doi: 10.3390/su71013726.

[51] R. W. Hermawan, B. E. Soetjipto, and W. P. Rahayu, "The Effect of Entrepreneurial SelfEfficacy and Locus of Control on Entrepreneurship Interest through Entrepreneurship Literacy," Int. Organ. Sci. Res. J. Bus. Manag., vol. 18, no. 2, pp. 141-148, 2016. 